American Journal of Applied Sciences 1(3): 220-224, 2004

ISSN 1546-9239

(C) Science Publications, 2004

\title{
A Computable General Equilibrium Model of Southern Region in Taiwan: The Impact of the Tainan Science-Based Industrial Park
}

\author{
${ }^{1}$ Chun-Chu Liu and ${ }^{2}$ Chia-Yon Chen \\ ${ }^{1,2}$ Department of Resources Engineering, National Cheng-Kung University, Taiwan, R.O.C \\ ${ }^{1}$ Department of International Business, Chang Jung Christian University, Taiwan, R.O.C
}

\begin{abstract}
The primary modeling tools used to analyze regional economic issues include econometric forecasting models, fixed price Input-Output (I-O) multi-sector models, Social Accounting Matrix (SAM) and Computable General Equilibrium (CGE) models. CGE models combine the advantages of econometric, I-O models and SAM strengthening the theoretical basis of the modeling effort and thus enabling more precise policy analysis. The current CGE literature includes models used to analyze international trade, tax reform, energy and environmental issues etc. However, application of this technique on a regional scale is rare in the scientific literature. In this study, a small regional computable general equilibrium model is constructed and applied to analyze the economic impact of constructing Tainan Science-Based Industrial Park (TSBIP) locating in the Southern Taiwan. The research results provide a valuable reference for decision-makers in formulating industrial and regional policies, as well as helping business managers with strategic planning.
\end{abstract}

Key words: Computable General Equilibrium, Taiwan, Tainan Science-Based Industrial Park

\section{INTRODUCTION}

Impact analysis can be defined as an assessment of change in overall economic activity as a rule of any special change in one or several economic activities ${ }^{[1]}$. Impact analysis in a region focuses on the interaction between economic policy changes and the implications of these changes in the local economy. In particular, it may reflect local or national concern about the effect of change on a variety of actors or agents within the local economy, such as a specific socioeconomic group, specific sectors, or specific locations. Changes in the level and distribution of local employment, income, sales and wealth are often the target of analysts in the context of regional planning ${ }^{[2]}$. There are several tools available to the analyst assess regional impacts of programs. For example, partial equilibrium models (Export-Base models, Benefit-cost analysis and Econometric models) and general equilibrium models (I-O model, SAM model and CGE model) may be used. Partial equilibrium models are limited in their analytic approach because they often focus on specific sectors, thus ignoring the larger economy-wide effects. Unlike partial equilibrium models, a general equilibrium model account for the interindustry linkages in an economy and is viewed as more appropriate framework for conducting economic impact analysis. General equilibrium models can be categorized into fixed-price models (I-O models and SAM models) and flexible price modes (CGE models). It is critical to the relative accuracy of estimates from the above two general equilibrium models. Fixed-price I-O models and SAM models, provide internally consistent representation of the regional economic structure. However, this consistency is arguably more realistic and explicit in a CGE than in either I-O or SAM.

In Taiwan, I-O models are the most common application of general equilibrium techniques used for regional economic impact analysis. Recently, CGE models have been proposed as an alternative analytical tool for policy analysis on a regional scale ${ }^{[3,4,5,6,7,8]}$. However, little attention has been devoted to inquiring about the economic impact analyze of important investment on a regional scale in Taiwan. CGE models allow for more flexibility and are more consistent with neoclassical economic theory and thus, may generate less biased estimates when compared with other modeling techniques ${ }^{[9]}$. The CGE approach permits prices of inputs to vary with respect to changes in output prices and, thus, allows it to capture the behavior of economic agents. It incorporates a variety of flexible production functions that allow producers to substitute cheaper inputs for more expensive inputs. This approach can also accommodate constraints on the availability of primary inputs and accounts for additional intersectoral linkages. For example, if the factors of production are limited in supply, the expansion in some sectors will draw factors of production from other sectors thereby causing a contraction in those industries.

CGE models have been proposed as an alternative analytical tool for policy analysis on a regional scale and are the focus of this study ${ }^{[3]}$. Contend that a regional CGE model is more theoretically grounded than supply-determined I-O models for impact analysis where the productive capacity of sectors is reduced in a regional economy. They conclude that although supplydetermined or mixed endogenous-exogenous SAM models are appropriate for addressing income 
distribution issues and are relatively easy to implement, they suffer with limited flexibility by assuming fixed prices and ignoring substitution effects in production and consumption. CGE models provide the flexibility necessary for improving analysis of a regional economy by overcoming the restrictive assumptions contained in I-O and SAM models.

Model formulation: In recent years, a growing number of researchers have begun to use the computable general equilibrium models to analyze the impacts of regional policies ${ }^{[3,4,5,6,7,8]}$. Therefore, in analyzing the impacts of constructing TSBIP locating in the Southern Taiwan, a computable general equilibrium approach is generally considered an appropriate tool. In the Southern Taiwan CGE (STCGE) model, there are two economic regions, Southern Taiwan and the rest of the word, which includes the Taiwan and all other countries. Economic agents operating in the two regions consist of producers, private households, local government and central government.

The computable general equilibrium model used is a static model, which follows closely in the ${ }^{[10]}$ tradition. Modifications include alternative function forms for production technology and disaggregate household groups. In the computable general equilibrium model, the Taiwan economy is divided into 14 sectors: (1) agriculture (i.e. Agriculture, forestry and fishing), (2) mining, (3) processed food, (4) other chemical products, (5) petroleum refineries, (6) iron and steel, (7) electrical and electronic machinery, (8) precision instruments, (9) other manufacturing, (10) construction, (11) electricity, gas and water (12) transport, (13) trade and eating-drinking places and (14) finance, service and others. The five equal divisions of household are specified, using the classification of The Report on the Survey of Family Income and Expenditure in Taiwan Area $^{[11]}$. A disaggregate social accounting matrix given in Table 1 is designed to reflect the circular flow of the Southern Taiwan economy that is embodied in Southern Taiwan's computable general equilibrium model is outlined below. The model is composed of production and factor markets, expenditure and income, foreign exchange market, prices, market equilibrium and macro close rule. The following paragraphs provide a general description of Southern Taiwan's computable general equilibrium model. The production process is assumed to take place in a two-stage process. In the first stage, producers select optimal quantities of capital and labor, using Cobb-Douglas (C-D) production Function $^{[9]}$. In the second stage, firms choose the intermediate inputs in combination with the primary inputs using a fixed-proportion Leontief production technology. Other production technology may be used at this stage. However, in most regional applications, the Leontief production technology is the preferred choice $^{[12]}$. Factor demands are derived from first-order conditions, using a conventional profit maximization approach. Labor and capital factors are perfectly mobile between economic sectors and are fully employed in the base year. The model has five household groups; for each household group there is a representative consumer who determines his consumption behavior from utility maximization. The consumer preferences are characterized by a Cobb-Douglas utility function for each representative consumer, this allows for different marginal budget shares for five household groups. The household budget account constitutes income revenue and expenditure. The main sources of household income revenue include labor income, distributed profits, government transfer and net transfer from abroad. Each household expenditure is allocated to private consumption, direct taxes and private saving. The two levels of government accounted for in the model are local and central government. Government actions have a significant influence on the economy through its income revenue and spending changes. The main sources of government revenues include indirect taxes, tariffs, enterprise taxes and direct taxes. Government spending constitutes government consumption, transfer to enterprise, transfer to household and government saving. Our model assumes government income revenue equal to income spending. The enterprise in this model includes private companies, public companies and nonprofit enterprise, using the aggregate catalogue of National Income in Taiwan Area ${ }^{[13]}$. The main sources of enterprise revenues include capital income, government transfer and net transfer from abroad. Main enterprise outlays include distributed profits, enterprise taxes and retained earnings. It is also assumed that enterprise income revenue equal to outlays. In this model, small-openeconomy assumptions are held, it implies that Southern Taiwan cannot affect world price with its exports and imports. The model assumes a float exchange rate mechanism and contains a balance-of-trade constraint. The value of total exports includes export trade, net labor income from abroad, net capital income from abroad, net transfer from abroad to enterprise and net transfer from abroad to the household. The value of total imports consists of import trade and net foreign borrowing. The model assumes imperfect substitution between imports and domestic goods, using the Armington constant elasticity of substitution function form $^{[14]}$. Thus, the import demand for a specific sector becomes derive demand. On the export side, the export demand for a specific commodity depends upon the world price of exported goods measured in foreign exchange units relative to price level of domestic goods. In a market equilibrium condition, we assume that the total supply of commodities equals the total demand for the commodities. As stated previously, the total supply of composite commodities is a CES combination of domestic goods and imports. Total demand consists of intermediate inputs, private consumption, government consumption and investment. 
American J. Appl. Sci., 1 (3), 220-224, 2004

Table 1: Structure of a Social Accounting Matrix for Southern Region in Taiwan, 1999 (million NT)

\begin{tabular}{|c|c|c|c|c|c|c|c|c|c|}
\hline \multirow[b]{3}{*}{ Receipts } & \multicolumn{9}{|l|}{ Expenditures } \\
\hline & \multirow[b]{2}{*}{ Activities } & \multirow[b]{2}{*}{ Commodities } & \multicolumn{2}{|l|}{ Factors } & \multicolumn{3}{|l|}{ Institutions } & \multirow{2}{*}{$\begin{array}{l}\text { Capital } \\
\text { Account }\end{array}$} & \multirow[b]{2}{*}{ Rest of World } \\
\hline & & & Labour & Capital & Enterprises & Households & Government & & \\
\hline Activities & & $\begin{array}{l}\text { Domestic } \\
\text { Sales } \\
4350884.84\end{array}$ & & & & & & & $\begin{array}{l}\text { Exports } \\
1777164.66\end{array}$ \\
\hline Commodities & $\begin{array}{l}\text { Intermediate } \\
\text { Inputs } \\
4105414.8\end{array}$ & & & & & $\begin{array}{l}\text { Private } \\
\text { Consumption } \\
1275734.13\end{array}$ & $\begin{array}{l}\text { Government } \\
\text { Consumption } \\
283354.03\end{array}$ & $\begin{array}{l}\text { Investment } \\
216326.5\end{array}$ & \\
\hline Factors: & & & & & & & & & \\
\hline Labor & $\begin{array}{l}\text { Wages } \\
1096700.18\end{array}$ & & & & & & & & $\begin{array}{l}\text { Net labor income } \\
\text { From abroad } \\
-57106.74\end{array}$ \\
\hline Capital & $\begin{array}{l}\text { Rentals } \\
546163.49\end{array}$ & & & & & & & & $\begin{array}{l}\text { Net capital income } \\
\text { From abroad } \\
110232.51\end{array}$ \\
\hline $\begin{array}{l}\text { Institutions: } \\
\text { Enterprises }\end{array}$ & & & & $\begin{array}{l}\text { Capital } \\
\text { Income } \\
656396\end{array}$ & & & $\begin{array}{l}\text { Government } \\
\text { Transfers } \\
70997.44\end{array}$ & & \\
\hline Households & & & $\begin{array}{l}\text { Labor } \\
\text { Income } \\
1039593.44\end{array}$ & & $\begin{array}{l}\text { Distributed } \\
\text { Profits } \\
547743.99\end{array}$ & $\begin{array}{l}\text { Household } \\
\text { Transfer } \\
13672.03\end{array}$ & $\begin{array}{l}\text { Government } \\
\text { Transfers } \\
109016.68\end{array}$ & & $\begin{array}{l}\text { Net transfer from } \\
\text { Abroad } \\
81198.55\end{array}$ \\
\hline Government & $\begin{array}{l}\text { Indirect } \\
\text { Taxes } \\
108419.54\end{array}$ & $\begin{array}{l}\text { Tariffs } \\
20466.01\end{array}$ & & & $\begin{array}{l}\text { Enterprise } \\
\text { Taxes } \\
34246.12\end{array}$ & $\begin{array}{l}\text { Direct } \\
\text { Taxes } \\
132266.16\end{array}$ & & & $\begin{array}{l}\text { Net transfer from } \\
\text { Abroad } \\
140.14\end{array}$ \\
\hline Capital Account & $\begin{array}{l}\text { Capital } \\
\text { Depreciation } \\
271351.49\end{array}$ & & & & $\begin{array}{l}\text { Retained } \\
\text { Earnings } \\
107094.6\end{array}$ & $\begin{array}{l}\text { Private } \\
\text { Saving } \\
298372.24\end{array}$ & $\begin{array}{l}\text { Government } \\
\text { Saving } \\
-78135.55\end{array}$ & & \\
\hline Rest of world & & $\begin{array}{l}\text { Imports } \\
1509478.61\end{array}$ & & & & $\begin{array}{l}\text { Foreign } \\
\text { Transfer } \\
19488.86\end{array}$ & $\begin{array}{l}\text { Foreign } \\
\text { Transfer } \\
305.37\end{array}$ & $\begin{array}{l}\text { Net foreign } \\
\text { borrowing } \\
382356.28\end{array}$ & \\
\hline
\end{tabular}

Source: ${ }^{[16]}$

Finally, according to ${ }^{[12]}$, the results of neoclassical closure in a regional context often are more consistent with econometric models. Hence, the neoclassical closure is adapted in the STCGE. In the computable general equilibrium model, the system can only determine relative prices and solve for prices relative to a numeraire. Because the STCGE is a regional model, the exchange rate is used as the numeraire good, following ${ }^{[15]}$.

Region, Data Sources, Calibration and Elasticity Specification: Southern region in Taiwan is composed of eight distinct counties or city: Chiayi city, Chiayi county, Tainan city, Tainan county, Kaohsiung city, Kaohsiung county, Pingtung County and Penghu County. This model is calibrated for the 1999 base year data set. The data on the Taiwan economy are organized in the social accounting matrix. A disaggregate social accounting matrix combines the Input-Output Table ${ }^{[16]}$ with the national income accounting. Therefore, disaggregate social accounting matrix is based on the national income accounting and adjust input-output data for consistency. In addition to the data in the input-output Table and national income accounting, the database for our computable general equilibrium model includes labor, capital, income distribution matrix, various elasticities and other parameters. The labor and capital data are from Year Book of Manpower Statistics ${ }^{[17]}$ and the Trends in
Multifactor Productivity ${ }^{[18]}$. A multi sector income distribution matrix is transformed income flows between industry and the five equal divisions of household. This matrix used is from the Report of Survey of Family Income and Expenditure ${ }^{[11]}$. In order to model production technology, composite commodity and export demand function, we need a variety of elasticity. Elasticities of production technology are constructed on the basis of the elasticities used in ${ }^{[19,20] \text {. }}$ Following ${ }^{[21]}$ we set the elasticity between domestic and imported goods and elasticity of export demand function. Calibrating against a benchmark equilibrium data set that is derived from above numerically specifies other parameters in this model. Simulation results are generated by using GAMS program ${ }^{[22]}$.

\section{RESULTS AND DISCUSSION}

Analyzing the impact of the establishment of TSBIP on the southern region in Taiwan's economy is performed in two stages. The first stage simulates the economic impact of the TSBIP construction phase. The second looks at the economy of the TSBIP when it is up and running. The construction planning of TSBIP will be implemented in two stages: the first stage is from July 1996 through December 2003 and the development area is 405.88 Hectares; the second stage is from January 2002 to December 2009 with 232.53 Hectares of development area. The total area developed covers 
638.42 Hectares. They anticipated that the construction cost of TSBIP is 39.86 billion NT dollars and the majority of the cost goes to land cost, planning application fee, construction cost and maintenance and operation cost. The sales of TSBIP in 1999 were as many as 1580 million NT dollars. It is estimated that in 2010 the sales can reach 990 billion NT dollars and 1584.7 billion NT dollars in 2021. Scenario 1, output effects reveal that the most impacted industries in southern Taiwan are iron and steel industry, other manufacturing industry, as well as the service industry, which account for $53 \%$ of total output variation in southern Taiwan. Employment effects reveal that the industries, which have a stronger employment effect in southern Taiwan, are iron and steel industry, other manufacturing industry, wholesale and retail industry, as well as food service industry, which claim $50 \%$ of total employment effect in southern Taiwan. Income effects reveal that the industries, which have a greater income effect in southern Taiwan, are iron and steel industry, other manufacturing industry, as well as the service industry, which explain $46 \%$ of total income effect in southern Taiwan. Scenario 2, output effects reveal that the industries which have a bigger output effect in southern Taiwan are power industry, electronics and mechanical equipment manufacturing industry (IC, computer and peripheral equipment Mfg and telecommunications), precision machinery manufacturing industry, as well as iron and steel industry, which claim $82 \%$ of total output effect in southern Taiwan. Employment effects reveal that the employment effect in southern Taiwan is mainly observed in the power industry, electronics and mechanical equipment manufacturing industry (IC, computer and peripheral equipment Mfg and telecommunications) and precision machinery manufacturing industry which are induced by TSBIP and then in commerce and service industries. Income effects reveal that the industries, which have a greater income effect in southern Taiwan, are in the same order as that of employment effect.

\section{CONCLUSION}

A regional computable general equilibrium model is constructed and is applied to analyze the economic impact of the establishment of TSBIP on the southern region in Taiwan's economy. Construction of the model required the following steps. Reviewing the current literature on regional impact models, describing the model in detail and the collection and reconciliation of data fit the model and completing the analysis of simulation. The limitations to this model regard the assumptions as to the functional form of the behavior of economic agents in consumption, production and so on, additional research are needed to relax those assumptions. Therefore, this study's simulation results are only the first step of policy making. Further results should need more detailed calculations and judgments.

\section{ACKNOWLEDGMENT}

The authors would like to thank the National Science Council of the Republic of China for financially supporting this research under Contract No. NSC89-2146-H-309-012-SSS.

\section{REFERENCES}

1. IMPLAN Group, 1996. Inc. User's Guide, IMPLANPro: Social Accounting and Impact Analysis Software, Stillwater, MN.

2. Shaffer, R., 1989. Community Economics: Economic Structure and Change in Smaller Communities. Iowa State Univ. Press, America.

3. Seung, C., T. Harris and T. MacDiarmid, 2000. Economic impacts of surface water reallocation policies: a comparison of supply determined SAM and CGE models. Reg. Anal. Policy, 27: 55-76.

4. Alavalapati, J., W. White and M. Patriquin, 1999. Economic impacts of changes in the forestry sector: a case study of the Foothills Region in Alberta. For. Chron. 75: 121-127.

5. Schreiner, D. F. And D. W. Marcouiller, 1999. Computable General Equilibrium Modeling for Regional Analysis. West Virginia Univ. Web Book.

6. Partridge, M. D. And D. Rickman, 1998. Regional Computable General Equilibrium Modeling: A Survey and Critical Appraisal. Int. Regional Sci. Rev., 21: 205-248.

7. Park, I. 1995. Regional Integration Among the Asian Nations A Computable General Equilibrium Model Study. Westport, Connecticut London.

8. Harrigan, F. and P. G. McGregor, 1989. Neoclassical and Keynesian perspectives on the regional macroeconomic: A computable general equilibrium approach. J. Regional Sci., 29: 555-73.

9. Shoven, J. B. And J. Whalley, 1992. Applying General Equilibrium. Cambridge Univ. Press.

10. Dervis, K., J. De Melo and S. Robinson, 1982. General Equilibrium Models for Development Policy. Cambridge: Cambridge Univ. Press.

11. Directorate-General of Budget, Accounting and Statistics (DGBAS), 1999. The report on the survey of family income and expenditure in Taiwan area, Executive Yuan, Taiwan, R.O.C.

12. Rickman, D. S., 1992. Estimating the Impacts of Regional Business Assistance Programs: Alternative Closures in A Computable General Equilibrium Model. Papers in Regional Sci., 71: 421-435.

13. Directorate-General of Budget, Accounting and Statistics (DGBAS), 1999. National income in Taiwan area, Executive Yuan, Taiwan, R.O.C.

14. Armington, P. 1969, A theory of demand for products distinguished by place of production, IMF Staff Papers, 16: 159-178. 
15. Sullivan, J., W. D. Mccollum and S.G. Alward, 1997. Regional CGE Models Based on IMPLAN Social Accounts: Experiments in Arizona and New Mexico, Paper Presented at the Annual Meetings of the Southern Regional Sci. Assoc., Memphis, TN April 17-19.

16. Directorate-General of Budget, Accounting and Statistics (DGBAS), 1999. Input-output Table, Executive Yuan, R.O.C.

17. Directorate-General of Budget, Accounting and Statistics (DGBAS), 1999. Year Book of Manpower Statistics, Executive Yuan, Taiwan, R.O.C.

18. Directorate-General of Budget, Accounting and Statistics (DGBAS), 1999. The trend in multifactor productivity, Executive Yuan, Taiwan, R.O.C.

19. Lin, S. M., 1998. Fuel taxes in Taiwan: Welfare impacts on regional and socioeconomic groups, Academia Economic Papers, 26: 71-100.
20. Burniaux, J. M., J. P. Martin, G. Nicoletti and J. O. Martins, 1992. GREEN: A Multi-Sector, MultiRegion Dynamic General Equilibrium Model for Quantifying the Costs of Cubing CO Emissions: A 2 Technical Manual, Economics Department Working Papers No. 116. OECD, Paris.

21. Chu, Y. P., 1996. Effects of Trade Liberalization on Taiwan's Economy: A Computable General Equilibrium Model, ISSP Working paper. Academia Sinica, Taipei.

22. Brook, A., D. Kendrick and A. Meeraus, 1992. GAMS: a user's guide, South San Francisco, The scientific press. 